\title{
RESPON KIAI BABAKAN CIWARINGIN CIREBON TERHADAP BANK SYARIAH
}

\author{
Mohamad Ghozali \\ Fakultas Syari'ah dan Ekonomi Islam \\ Institut Agama Islam Negeri Syekh Nurjati Cirebon \\ email: ghozali.iaincrb@gmail.com
}

\begin{abstract}
Islamic bank is an institution established in Indonesia recently, so most people still do not know and understand the mechanism, products and principles used by the Sharia banks. So there are many segments of society that should be targeted in an optimal socialization, including merchants and assessed as a driver of economic actors in society, the market traders have an important position for the optimization and business expansion efforts for Sharia banks. The method used in this research is to use a quantitative approach that seeks to draw the factors and information from field data encountered a number to be analyzed further by linking variables then be concluded. From the data analysis it can be concluded that 95.5\% of the socioeconomic status Tegalgubug clothing wholesale market traders in terms of the dimensions of education, employment, wealth, including the accessibility and position in the intermediate category and overall response Tegalgubug clothing wholesale market traders against sharia bank was very positive, which is 91\% categorized as good and 9\% excellent category. While the socio-economic status of the clothing wholesale market traders sharia banks there is a significant correlation.
\end{abstract}

Kata Kunci: Respon, Bank Syariah.

\begin{abstract}
Abstrak
Bank syariah merupakan lembaga yang belum lama berdiri di Indonesia, sehingga sebagian besar masyarakat masih belum mengetahui dan memahami mekanisme, produk dan prinsipprinsip yang digunakan oleh bank syariah. Sehingga masih banyak segmen masyarakat yang harus menjadi sasaran sosialisasi secara optimal, termasuk pedagang yang dinilai sebagai penggerak dan pelaku ekonomi di masyarakat, yakni pedagang pasar mempunyai kedudukan penting bagi upaya optimalisasi dan ekspansi bisnis bagi bank syariah. Metode yang digunakan dalam penelitian ini adalah dengan menggunakan pendekatan kuantitatif yang berupaya menarik faktor-faktor dan informasi-informasi dari data lapangan yang ditemui secara angka untuk dianalisis lebih lanjut dengan menghubungkan variabel-variabel yang kemudian diambil kesimpulan. Dari analisis data dapat disimpulkan bahwa 95,5\% status sosial ekonomi pedagang pasar induk sandang Tegalgubug ditinjau dari dimensi pendidikan, pekerjaan, kekayaan, aksesabilitas dan kedudukan termasuk dalam kategori menengah. dan secara keseluruhan respon pedagang pasar induk sandang Tegalgubug terhadap bank syariah adalah sangat positif, yakni 91\% termasuk kategori baik dan 9\% termasuk kategori sangat baik. Sedangkan antara status sosial ekonomi pedagang pasar induk sandang terhadap bank syariah terdapat korelasi yang signifikan.
\end{abstract}

Keywords: Response, Bank Syariah. 


\section{PENDAHULUAN}

Penelitian ini dilatar belakangi, pertama fakta bahwa mayoritas penduduk Indonesia beragama Islam, dan mayoritas secara fiqhiyah tidak menyetujui bunga bank, namun dalam praktiknya bentuk kegiatan usaha, produk, dan jasa perbankan syariah (yang secara konseptual tidak berdasar pada bunga kurang dimengerti dan di pahami oleh masyarakat secara komprehensif, yang menyebabkan kurangnya minat masyarakat untuk menggunakan bank syariah). Fakta menunjukkan bahwa selama 10 tahun sejak berdirinya bank syariah di Indonesia, total pangsa pasar bank ataupun institusi syariah belum mampu bersaing secara siginifikan dengan pangsa pasar bank secara nasional.

Hal ini salah satunya dapat dilihat dari pangsa kegiatan usaha perbankan syariah terhadap perbankan nasional sampai dengan bulan Juni tahun 2015, yaitu asset perbankan syariah terhadap perbankan nasional baru mencapai sekitar 1,58\% dari total aset perbankan nasional, dana pihak ketiga $1,61 \%$ dari total dana pihak ketiga perbankan nasional dan pembiayaan 2,58 \% dari total pembiayaan/ kredit perbankan nasional. ${ }^{1}$

Kedua, bank syariah merupakan lembaga yang belum lama berdiri di Indonesia, sehingga sebagian besar masyarakat masih belum mengetahui dan memahami mekanisme, produk dan prinsipprinsip yang digunakan oleh bank syariah. ${ }^{2}$ Selain itu, karena penyebaran kantor operasional bank syariah yang belum merata.

Berdirinya perbankan syariah, didasarkan pada dua alasan utama, yaitu pertama, adanya pandangan bahwa bunga (interest) pada bank konvensional hukumnya haram karena termasuk dalam kategori riba yang dilarang dalam agama, bukan saja pada agama Islam tetapi juga

${ }^{1}$ http//www.bi.go.id. Diakses pada tanggal 10 Maret 2017.

${ }^{2}$ M.Syafi'I Antonio, Bank Syariah dari Teori ke Praktek, cet. I (Jakarta: Gema Insani Press, 2001), 4. oleh agama samawi lainnya. Dan kedua, dari aspek ekonomi, penyerahan risiko usaha terhadap salah satu pihak dinilai melanggar norma keadilan. Faktor utama yang membedakan bank konvensional dengan bank syariah adalah suku bunga (interest) sebagai balas jasa atas penyertaan modal yang diterapkan pada bank konvensional, sementara pada bank syariah balas jasa atas modal diperhitungkan berdasarkan keuntungan atau kerugian yang diperoleh yang didasarkan pada "akad". Prinsip utama dari "akad" ini adalah keadilan antara pemberi modal dan pemakai modal. Prinsip ini berlaku baik bagi debitur maupun kreditur.

Kalangan perbankan syariah menyadari bahwa pengembangan perbankan syariah membutuhkan komitmen yang tinggi dari semua pihak guna bersama-sama memajukan perbankan syariah. Kalangan perbankan syariah juga menyadari bahwa masih ada berbagai kelemahan dan tantangan yang harus segera di selesaikan agar perkembangan bank syariah dapat lebih pesat lagi dimasa-masa yang akan datang. Kelemahan dan tantangan itu antara lain, 1) kerangka dan perangkat peraturan perbankan syariah yang belum lengkap, 2) institusi pendukung yang belum lengkap dan efektif, 3) efisiensi operasional yang belum optimal, 4) porsi skim pembiayaan dengan prinsip bagi hasil yang masih perlu ditingkatkan, 5) kemampuan untuk memenuhi standar keuangan syariah internasional yang harus ditingkatkan, 6) cakupan pasar yang masih terbatas, dan 7) kurangnya pengetahuan dan pemahaman masyarakat mengenai produk dan jasa perbankan syariah. $^{3}$

Cakupan pasar yang masih terbatas dan kurangnya pengetahuan dan pemahaman masyarakat mengenai produk dan jasa bank syariah merupakan kelemahan sekaligus tantangan tersendiri bagi dunia

${ }^{3}$ Asmawi, "Respon Guru Madrasah terhadap Bank Syariah di Kabupaten Bogor", Laporan Penelitian, (Jakarta: Fakultas Syariah dan Hukum UIN Jakarta, 2004), 2. 
perbankan syariah nasional. Masih banyak segmen masyarakat yang harus menjadi sasaran sosialisasi yang optimal, termasuk segmen masyarakat yang dinilai sebagai penggerak dan motivator masyarakat, yakni kiai. Dengan fungsinya sebagai penggerak sekaligus motivator masyarakat ini, kiai mempunyai kedudukan penting bagi upaya sosialisasi bagi bank syariah. Seperti menjelaskan kepada masyarakat bahwa perbankan syariah pada dasarnya adalah penerapan (tathbiq) figh mu'amalah maaliyah. Atas dasar itu, sangat urgen kiranya dilakukakan suatu riset mengenai respon kiai terhadap bank syariah.

Adapun Desa Babakan Ciwaringin Kab. Cirebon merupakan salah satu basis pondok pesantren terbesar di Jawa Barat khususnya dan Indonesia pada umumnya, sejak berdiri sekitar 300 tahun yang telah silam kini pondok pesantren Babakan Ciwaringin Cirebon telah banyak melahirkan cabang pondok pesantren dengan penamaan yang berbeda-beda dilingkungan pondok pesantren Babakan. Sehingga jumlah santri Babakan sekarang secara keseluruhan berjumlah lebih kurang 5000 orang. $^{4}$

Oleh karena itu, penulis merasa perlu untuk melakukan penelitian tentang respon kiai Babakan Ciwaringin Cirebon terhadap bank syariah dan hubungannya dengan status sosial ekonomi mereka yang dirumuskan dengan judul penelitian sebagai berikut: Respon Kiai Babakan Ciwaringin Cirebon Terhadap Bank Syariah; Hubungan Status Sosial Ekonomi Dengan Responnya Terhadap Bank Syariah.

\section{RESPON KIAI BABAKAN CIWARINGIN ATAS BANK SYARIAH}

Respon kiai tentang suatu masalah bisa terbentuk oleh sejumlah faktor, baik yang bersifat internal maupun eksternal. Salah

${ }^{4}$ Tim Penyusun Panitia Akhirussanah, Kenang-kenangan angkatan ke-42 Madrasah AlHikamus Salafiyah Babakan Ciwaringin Cirebon Tahun 2000, Buku Agenda Alumni (Cirebon: ttp., 2000), 19. satu diantaranya latar belakang status sosial ekonomi. Status sosial ekonomi merupakan manifestasi dalam kehidupan seseorang. Maka, status sosial ekonomi kiai, dapat dihipotesiskan bisa mempengaruhi terbentuknya respon kiai terhadap bank syariah. Atas dasar itu, penelitian tentang respon kiai terhadap bank syariah perlu dikaitkan masalahnya dengan latar belakang status sosial ekonomi mereka. Beberapa teori yang dihadirkan untuk melihat respon kiai Babakan Ciwaringin Cirebon atas kehadiran bank syariah adalah sebagai berikut:

\section{Teori Sikap (Attitude)}

Menurut Norman L. Munn dan Houghton Miffin dalam Asmawi respon merupakan varian sikap yakni sikap menerima atau menolak. Jadi, diskusi tentang respon berarti diskusi tentang sikap (attitude). ${ }^{5}$

Thurstone dalam Bimo Walgito memandang sikap sebagai suatu tingkatan afeksi, baik yang bersifat positif maupun negatif dalam hubungan dengan objek-objek psikologis. Dengan demikian, objek dapat menimbulkan berbagai macam sikap, berbagai macam tingkatan afeksi pada seseorang. Dalam pandangan Thurstone, sikap hanya mengandung komponen afeksi saja. ${ }^{6}$

Sarlito W. Sarwono menegaskan bahwa sikap adalah kesiapan pada seseorang untuk bertindak secara tertentu terhadap halhal tertentu. Sikap merupakan suatu aspek psikis yang berbeda dengan aspek-aspek psikis yang lain, seperti motif, kebiasaan dan pengetahuan. ${ }^{7}$

Bimo Walgito menyimpulkan bahwa sikap itu merupakan organisasi pendapat, keyakinan seseorang mengenai objek atau situasi yang relatif ajeg, yang disertai adanya perasaan tertentu, dan memberikan dasar pada orang tersebut untuk membuat

\footnotetext{
${ }^{5}$ Asmawi, Respon Guru Madrasah terhadap Bank Syariah, 5.

${ }^{6}$ Bimo Walgito, Psikologi sosial; Suatu Pengantar (Yogyakarta: Penerbit ANDI, 2002), 109.

${ }^{7}$ Sarlito W. Sarwono, Pengantar Umum Psikologi (Jakarta: Bulan Bintang, 1976), 86-114.
} 
respons atau berperilaku dalam cara tertentu yang dipilihnya. ${ }^{8}$

Terdapat beberapa faktor yang menjadi determinan sikap, yakni (1) faktor pengalaman langsung terhadap objek, (2) faktor kerangka acuan dan (3) faktor komunikasi sosial. Keempat faktor ini diyakini dapat mempengaruhi arah sikap (positif atau negatif) dan intensitas sikap. ${ }^{9}$

\section{Teori Nilai}

Nilai adalah pandangan yang dianut oleh suatu masyarakat, mengenai apa yang dianggap baik dan apa yang dianggap buruk oleh masyarakat. Woods mendefinisikan nilai sebagai petunjuk umum yang telah berlangsung lama, yang mengarahkan tingkah laku dan kepuasan dalam kehidupan sehari-hari.

Dalam konteks sosial nilai memiliki ciri di antaranya sebagai berikut; 1) konstruksi masyarakat sebagai hasil interaksi antarwarga masyarakat, 2) disebarkan diantara warga masyarakat (bukan bawaan lahir), 3) terbentuk melalui sosialisasi (proses belajar), 4) bagian dari usaha pemenuhan kebutuhan dan kepuasan sosial manusia, 5) bervariasi antara kebudayaan yang satu dengan kebudayaan yang lain, 6) dapat mempengaruhi pengembangan diri social, 7) memiliki pengaruh yang berbeda antarwarga masyarakat, dan 8) cenderung berkaitan satu sama lain.

Berdasarkan ciri-cirinya, nilai dapat dibagi menjadi dua macam, yaitu nilai dominan dan nilai mendarah daging (internalized value).

Bagi manusia, nilai berfungsi sebagai landasan, alasan, atau motivasi dalam segala tingkah laku dan perbuatannya. Nilai mencerminkan kualitas pilihan tindakan dan pandangan hidup seseorang dalam masyarakat. ${ }^{10}$

\footnotetext{
${ }^{8}$ Bimo Walgito, Psikologi sosial; Suatu Pengantar, 110.

${ }^{9}$ Bimo Walgito, Psikologi sosial; Suatu Pengantar, 112.

${ }^{10} \mathrm{http}: / /$ www.pembelajar.com/wmview.php?A rtID=951. Diakses pada tanggal 21 April 2016.
}

\section{Teori kepercayaan}

Kepercayaan (belief) secara umum memiliki arti pengakuan akan kebenaran terhadap suatu perkara. Biasanya, seseorang yang menaruh kepercayaan pada sesuatu perkara itu akan disertai oleh perasaan 'pasti' atau kepastian terhadap perkara yang bersangkutan.

Sedangkan kepercayaan (belief) dalam konteks psikologi adalah suatu keadaan jiwa yang berkaitan dengan sikap berkedudukanmemihak (propositional attitude). Manakala dalam konteks agama pula, kepercayaan adalah sebagian daripada pondasi pembangunan moral. Dalam konteks ini, kepercayaan dikenali sebagai Akidah ataupun Iman.

Adapun kepercayaan itu dikatakan berkaitan dengan sikap berkedudukanmemihak, karena ia senantiasa melibatkan penekanan, penuntutan, dan sangkaan dari seorang individu mengenai kebenaran sesuatu. Kebenaran yang dituntut itu mungkin benar, dan mungkin salah secara objektif, tetapi bagi individu yang bersangkutan ia adalah benar.

Berdasarkan definisi dalam kamus elektronik Encarta sistem kepercayaan ini terdiri dari beberapa hal, yaitu pertama, penerimaan terhadap kebenaran yang diyakini. Kedua, percaya akan sesuatu. Ketiga, prinsip-prinsip atau doktrin yang diterima sebagai suatu kebenaran. Dan keempat, Suatu pendapat yang diyakini kebenarannya. ${ }^{11}$

\section{Teori Status Sosial Ekonomi}

Secara etimologis, pengertian status sosial ekonomi terdiri dari kata status, sosial dan ekonomi. Status berarti keadaan, kedudukan (orang, benda, dan sebagainya) dalam hubungan dengan masyarakat disekelilingnya. $^{12}$ Sosial adalah berkenaan

\footnotetext{
${ }^{11}$ http://ms.wikipedia.org/wiki/Kepercayaan. Diakses pada tanggal 25 April 2016.

${ }^{12}$ Departemen Pendidikan dan Kebudayaan, Kamus Besar Bahasa Indonesia (Jakarta: Balai Pustaka, 1988), 858.
} 
dengan masyarakat. ${ }^{13}$ Sedangkan yang dimaksud dengan ekonomi ialah Pemanfaatan uang, tenaga, waktu dan sebagainya yang berharga. ${ }^{14}$

Secara terminologis, J. Dwi Narwoko mengartikan status sosial secara terpisah dengan pengertian ekonomi yaitu tempat seseorang didalam masyarakat sehubungan dengan orang lain, dalam arti lingkungan pergaulannya, prestisenya, hak-hak dan kewajibannya. ${ }^{15}$

Senada dengan J. Dwi Narwoko, Hendropuspito mengartikan status sosial terpisah dengan ekonomi, yaitu tempat yang diambil seseorang dalam masyarakat. Pengertian tempat tidak diartikan secara geografis, yakni lokasi fisik tertentu yang di duduki seseorang, melainkan secara sosiokultural, dengan lokasi di dalam pikiran orang atau kelompok orang yang tinggal dalam satuan budaya itu. ${ }^{16}$

Sementara Thamrin Nasution mengartikan status sosial ekonomi secara utuh yaitu suatu tingkatan yang dimiliki oleh seseorang yang didasarkan pada kemampuan dalam memenuhi kebutuhan hidup sehari-sehari dari penghasilan atau pendapatan yang diperoleh sehingga mempunyai peranan pada status sosial seseorang dalam struktur masyarakat. Penghasilan atau pekerjaaan tertentu juga dapat menentukan tinggi rendahnya status seseorang. $^{17}$

Pengertian diatas diperkuat lagi oleh Maftuh dan Ruyadi dengan bahasa yang lebih sederhana, bahwa status sosial ekonomi ialah status seseorang dalam

\footnotetext{
${ }^{13}$ Departemen Pendidikan dan Kebudayaan, Kamus Besar Bahasa Indonesia, 855.

${ }^{14}$ Departemen Pendidikan dan Kebudayaan, Kamus Besar Bahasa Indonesia, 220.

${ }^{15}$ J. Dwi Narwoko dan Bagong Suyanto, Sosiologi: Teks Pengantar dan Terapan, cet. I (Jakarta: Kencana: 2004), 136.

${ }^{16}$ D. Hendropuspito OC., Sosiologi Sistematik, cet. I (Yogyakarta: Kanisius, 1989), 103.

${ }^{17}$ Thamrin Nasution dan Muhammad Nur, Peranan Orang Tua Dalam Meningkatkan Prestasi Belajar Anak, cet. I (Bandung: Angkasa, 1990), 220.
}

masyarakat dilihat dari segi pendapatan, kekayaan dan jabatan. ${ }^{18}$

Dari beberapa pengertian diatas maka dapat disimpulkan bahwasanya yang dimaksud dengan status sosial ekonomi ialah suatu keadaan, posisi atau tingkatan seseorang dalam kehidupan bermasyarakat yang didasarkan atas latar belakang pendidikan, pekerjaan, kekayaan, dan kedudukan.

\section{Teori Bank syariah}

Menurut UU Republik Indonesia Nomor 10 Tahun 1998 tentang perubahan atas UU nomor 7 Tahun 1992 tentang Perbankan bahwa Bank Umum adalah bank yang melaksanakan kegiatan usaha secara konvensional dan/atau berdasarkan prinsip syariah yang dalam kegiatannya memberikan jasa dalam lalu lintas pembayaran. Sedangkan pengertian prinsip syariah itu sendiri adalah aturan perjanjian berdasarkan hukum Islam antara bank dengan pihak lain untuk penyimpanan dana dan/atau pembiayaan kegiatan usaha, atau kegiatan lainnya yang dinyatakan sesuai dengan syariah, antara lain, pembiayaan berdasarkan prinsip bagi hasil (mudharabah), pembiayaan berdasarkan prinsip penyertaan modal (musyarakah), prinsip jual beli barang dengan memperoleh keuntungan (murabahah), atau pembiayaan barang modal berdasarkan prinsip sewa murni tanpa pilihan (ijarah), atau dengan adanya pilihan pemindahan kepemilikan atas barang yang disewa dari pihak bank oleh pihak lain (ijarah wa iqtina). ${ }^{19}$

Menurut Karnaen A. Perwataatmadja dalam Muhammad Firdaus dkk, menyatakan bahwa "bank syariah adalah bank yang beroperasi sesuai dengan prinsip-prinsip Islam, yakni bank dengan tata cara dan

${ }^{18}$ Bunyamin Maftuh dan Yadi Ruyadi, Penuntun Belajar Sosiologi, cet. I (Bandung: Ganeca Exact, 1995), 3.

${ }^{19}$ C.S.T. Kansil, eds., Pokok-Pokok Pengetahuan Hukum Dagang Indonesia, cet. I (Jakarta: Sinar Grafika, 2002), 311-313. 
operasinya mengikuti ketentuan-ketentuan syariah Islam". ${ }^{20}$

Dari pengertian diatas penulis dapat menyimpulkan bahwa yang dimaksud dengan bank syariah adalah lembaga keuangan yang berfungsi sebagai penghimpun dana dan menyalurkannya kembali kepada masyarakat. Di mana sistem, tata cara dan mekanisme kegiatan usahanya didasarkan pada syariat Islam, yaitu Al-Qur'an dan Al-Hadis.

\section{FAKTOR-FAKTOR \\ YANG MEMPENGARUHI STATUS SOSIAL EKONOMI}

Dalam menentukan status sosial ekonomi seseorang atau kelompok dalam kehidupan bermasyarakat dipengaruhi oleh beberapa aspek, yaitu:

\section{Pendidikan}

Pendidikan dapat digunakan untuk menentukan status sosial ekonomi seseorang dalam kehidupannya sehari-hari. Hal ini dapat dilihat dari pendidikan terakhir yang ditamatkan.

Yang dimaksud dengan pendidikan yang ditamatkan adalah selesai mengikuti pelajaran pada kelas tertinggi suatu sekolah sampai akhir dengan mendapatkan tanda tamat/ijazah. Pendidikan yang ditamatkan dibagi menjadi 5 golongan, yaitu prtama, sekolah Dasar (SD)/MI/ Sederajat. Kedua, Sekolah Lanjutan Tingkat Pertama (SLTP)/ MTs/ Kejuruan/ Sederajat. Ketiga, Sekolah Menengah Umum (SMU) /MA/ Kejuruan/ Sederajat. Keempat, Diploma (DI/DII/DIII). Dan kelima, Sarjana (S1/S2/S3). ${ }^{21}$

\section{Pekerjaan}

Pekerjaan ialah fungsi atau tugastugas yang harus dilaksanakan menurut kedudukan seseorang di dalam lingkup

\footnotetext{
${ }^{20}$ Muhammad Firdaus NH, eds., Konsep \& Implementasi Bank Syariah, cet. I (Jakarta: Renaisan, 2005), 18.

${ }^{21}$ Syafri Hamid, Asas-asas Sosiologi (Bandung: Fakultas Hukum Universitas Islam Bandung, 1995), 212.
}

pekerjaan atau kejuruan tertentu. ${ }^{22}$ Orang yang melakukan pekerjaan disebut tenaga kerja. Pekerjaan seseorang dapat menentukan status sosial ekonomi karena didalam pekerjaan terdapat kedudukan.

Menurut Sensus Penduduk tahun 2000 tenaga kerja dibedakan berdasarkan status pekerjaan terdiri dari pertama, pekerja keluarga adalah status pekerjaan bagi mereka yang bekerja untuk keluarganya dengan tidak mendapat upah/gaji baik berupa uang maupun barang. Contohnya: ibu rumah tangga.

Kedua, perusaha sendiri tanpa dibantu orang lain adalah mereka yang berusaha/bekerja atas resiko sendiri dan tidak mempekerjakan pekerja keluarga maupun buruh. Contohnya sopir taksi yang membawa mobil atas risiko sendiri, kulikuli di pasar, stasiun atau tempat-tempat lainnya yang tidak mempunyai majikan tertentu. Ketiga, karyawan dengan upah dan gaji adalah mereka yang bekerja pada orang lain atau instansi/kantor/perusahaan dengan menerima upah/gaji, baik berupa uang maupun barang.

Keempat, berusaha dengan dibantu pekerja keluarga dan/atau karyawan tidak tetap adalah status pekerjaan bagi mereka yang bekerja sebagai orang yang berusaha atas resiko sendiri dan dalam usahanya mempekerjakan buruh tidak tetap. Contohnya, pengusaha warung yang dibantu oleh anggota rumah tangganya atau orang lain yang diberi upah tidak tetap, penjaja keliling yang dibantu anggota rumah tangganya atau seseorang yang diberi upah hanya pada saat membantu saja.

Dan kelima, Berusaha dengan karyawan tetap adalah mereka yang bekerja sebagai orang yang berusaha atas risiko sendiri dan dalam usahanya mempekerjakan paling sedikit satu orang buruh tetap. Buruh tetap adalah buruh/karyawan yang bekerja pada orang lain, instansi, kantor, ataupun perusahaan dengan menerima upah atau gaji

${ }^{22}$ http://www.nakertrans.go.id/pusdatinnaker/i nformasi/Istilah_Umum.htm. Diakses pada tanggal 11 Mei 2017. 
secara tetap, baik ada kegiatan maupun tidak. Contohnya pemilik toko yang mempekerjakan satu/lebih buruh tetap dan pengusaha sepatu yang memakai buruh tetap. $^{23}$

\section{Kekayaan}

Kekayaan dapat dijadikan suatu kriteria dalam menentukan status sosial ekonomi seseorang. Ukuran kekayaan seseorang dapat berupa tanah, modal, penghasilan, tabungan, deposito dan lainlain. $^{24}$ Barang siapa yang mempunyai kekayaan yang banyak akan menempati status sosial ekonomi yang tinggi.

\section{Kedudukan}

Hendropuspito membagi kedudukan menjadi dua, yaitu pertama, kedudukan resmi ialah kedudukan yang diambil seseorang dalam satuan sosio-budaya yang resmi. Dengan kata lain, kedudukan itu diakui secara resmi oleh lingkungan masyarakat itu. Secara formal ada surat keputusan atau pengangkatan dari pihak yang berwenang yang didalamnya dicantumkan ketentuan-ketentuan yang jelas tentang hak dan kewajiban yang melekat pada kedudukan tersebut.

Dan kedua, kedudukan tidak resmi ialah kedudukan yang diambil seseorang dalam satuan sosio-budaya yang tak resmi. Orang yang bersangkutan diterima umum berdasarkan kaidah-kaidah serta nilai-nilai sosial yang berlaku dilingkungan kultural itu. Serta didalam penerimaan itu tidak ada upacara dan surat pengangkatan resmi. ${ }^{25}$

\section{BANK SYARIAH DALAM PERSPEKTIF HUKUM ISLAM}

Dalam khasanah keilmuan Islam, istilah bank memang tidak dikenal. Akan tetapi dalam urusan muamalah terdapat suatu kaidah Ushul yang disepakati Fuqaha, yaitu:

$$
\text { تحريمها على ليل آلد يدل أن إلا باحة ألإِ ت }
$$

Artinya: Pada dasarnya semua bentuk Muamalah boleh dilakukan kecuali ada dalil yang mengharamkannya. ${ }^{26}$

Ini berarti ketika suatu transaksi baru muncul dimana belum dikenal sebelumnya dalam hukum Islam, maka transaksi tersebut dianggap diterima, kecuali terdapat implikasi dalil al-Qur'an dan al-Hadis yang melarangnya secara eksplisit maupun implisit. Begitu pula Islam menyikapi perbankan, pada dasarnya praktek perbankan boleh dilakukan, kecuali bila dalam melaksanakan fungsinya, bank melakukan hal-hal yang dilarang syariah. ${ }^{27}$

Landasan syariah operasional perbankan syariah salah satunya adalah ayat Al-Quran surat al-Baqarah ayat 275:

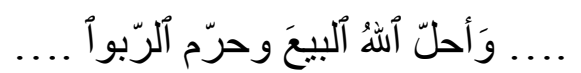

Artinya: Allah telah menghalalkan jual beli dan mengharamkan riba. (QS. Al-Baqarah [2]: 275). ${ }^{28}$

Begitu juga Hadis Rosulullah SAW yang diriwayatkan oleh Ibnu Majah di bawah ini:

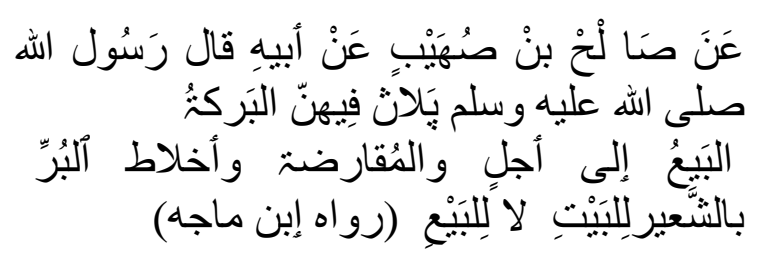

${ }^{26}$ Minhajuddin, Kaidah-kaidah Ushul Fiqh (Makasar: CV Berkah Utami, 1999), 11.

${ }^{27}$ Biro Perbankan Syariah-BI, Islam dan nt/view/806/806/. Diakses pada tanggal 03 April 2017.

${ }^{24}$ Hartomo dan Arnicun Aziz, Ilmu Sosial Dasar (Jakarta: Bumi Aksara, 1993), 203.

${ }_{25}$ Hendropusppito, Sosiologi Sistematik, 103104.
Perbankan Syariah (Jakarta: Karim Business Consulting, 2001), 5.

${ }^{28}$ M.Syafi'I Antonio, Bank Syariah dari Teori ke Praktek, 102. 
Artinya: Dari Shalih bin Shuhaib r.a. Rosulullah saw. bersabda, "Tiga hal yang didalamnya terdapat keberkatan: jual beli secara tangguh, Muqaradhah (mudharabah), dan mencampur gandum dengan tepung untuk keperluan rumah, bukan untuk dijual." (HR Ibnu Majah no.2280, kitab at-tijarah). ${ }^{29}$

Dalam praktek perbankan konvensional yang dikenal saat ini fungsi bank dilakukan berdasarkan sistem bunga. Sedangkan bunga telah diharamkan oleh mayoritas ulama.

Diantaranya menurut Lajnah Bahtsul Masa'il Nahdlatul Ulama, yaitu hukum bank dan bunganya sama seperti hukum gadai. Terdapat tiga pendapat ulama sehubungan dengan masalah ini. Yaitu; 1) Haram, sebab utang yang dipungut rente. 2) Halal, sebab tidak ada syarat pada waktu akad, sedangkan adat yang berlaku tidak dapat begitu saja dijadikan syarat. 3) Syubhat, sebab para ahli hukum berselisih pendapat tentangnya. ${ }^{30}$

Menurut Majlis Tarjih Muhamadiyah tahun 1968 memutuskan: 1) riba hukumnya haram dengan nash sharih al-Qur'an dan asSunnah, 2) bank dengan sistem riba hukumnya haram dan bank tanpa riba hukumnya halal, 3) bunga yang diberikan oleh bank-bank milik negara kepada para nasabahnya atau sebaliknya yang selama ini berlaku, termasuk perkara musytabihat, 4) menyarankan kepada PP Muhamadiyah untuk mengusahakan terwujudnya konsepsi sistem perekonomian, khususnya lembaga perbankan yang sesuai dengan kaidah Islam. $^{31}$

Menurut Lembaga Riset Islam AlAzhar dalam Muktamar Islam ke-2 memutuskan diantaranya: 1) Bunga

\footnotetext{
${ }^{29}$ Syafi' I Antonio, Bank Syariah dari Teori ke Praktek, 96.

${ }^{30}$ Syafi' I Antonio, Bank Syariah dari Teori ke Praktek, 63.

${ }^{31}$ Syafi' I Antonio, Bank Syariah dari Teori ke Praktek, 62.
}

(interest) dari semua jenis pinjaman hukumnya riba dan diharamkan, 2) Riba (bunga) yang banyak dan sedikit sama haramnya, 3) meminjamkan sesuatu dengan bunga (riba) tidak di benarkan apapun alasannya, baik karena keperluan maupun alasan darurat. ${ }^{32}$

\section{BANK SYARIAH DALAM SISTEM PERBANKAN DI INDONESIA}

Dalam hal sistem perbankan, di Indonesia menganut Dual Banking System, yakni disamping adanya sistem perbankan konvensional yang sudah berkembang sejak lama, juga telah diakui adanya sistem perbankan Islam atau yang lebih di kenal dengan perbankan syariah.

Dengan diberlakukannya UU No. 10 tahun 1998 tentang perubahan UU No. 7 tahun 1992 tentang perbankan yang diikuti dengan dikeluarkannya sejumlah ketentuan pelaksana dalam bentuk SK Direksi BI, baru dianggap telah memberikan landasan hukum yang lebih kuat dan kesempatan yang lebih luas bagi pengembangan bank syariah di Indonesia. Selain itu UU No. 23 tahun 1999 tentang Bank Indonesia juga menugaskan BI untuk mempersiapkan perangkat peraturan dan fasilitas-fasilitas penunjang yang mendukung operasional bank syariah.

Pada dasarnya ketentuan UU yang telah dikeluarkan pemerintah antara lain UU No. 7 tahun 1992, UU No. 10 tahun 1998 kemudian UU No. 23 tahun 1999 sudah menjadi dasar hukum yang cukup kuat bagi terselenggaranya opersional bank syariah di Indonesia. Namun demikian, masih ada beberapa hal yang perlu disempurnakan antara lain perijinan dan penyempurnaan serta undang-undang operasional perbankan syariah secara mandiri, sebab undangundang yang telah ada merupakan dasar hukum bagi penerapan dual banking system.

Dual banking system yang dimaksud adalah terselenggaranya dua sistem perbankan (konvensional dan syariah secara

${ }^{32}$ Yusuf Al-Qardhawi, Bunga Bank Haram, terj. Setiawan Budi Utomo, cet. II (Jakarta: Akbar Media Eka Sarana, 2002), 146. 
berdampingan) yang pelaksanaannya diatur dalam berbagai peraturan perundangundangan yang berlaku. Sehingga yang terjadi adalah bank syariah tidak berdiri sendiri (mandiri) dalam opersionalisasinya, yakni masih menginduk kepada bank konvensional.

Bila demikian adanya perbankan syariah hanya menjadi salah satu bagian dari program pengembangan bank konvensional, padahal yang dikehendaki adalah bank syariah yang betul-betul mandiri dengan berbagai perangkatnya sebagai bagian yang diakui secara nasional. ${ }^{33}$

\section{METODOLOGI PENELITIAN}

Metode yang digunakan dalam penelitian ini adalah dengan menggunakan pendekatan kuantitatif yang berupaya menarik faktorfaktor dan informasi-informasi dari data lapangan yang ditemui secara angka untuk dianalisis lebih lanjut dengan menghubungkan variabel-variabel yang kemudian diambil kesimpulan. Untuk lebih lanjut, di bawah ini akan dijelaskan beberapa instrumen yang digunakan dalam penelitian kali ini, yaitu sebagai berikut:

\section{Populasi dan Sampel Penelitian}

Populasi dan sampel dalam penelitian ini adalah kiai atau pengasuh pondok pesantren yang berjumlah 22 orang. Karena terbatasnya populasi, maka keseluruhan populasi dijadikan sampel penelitian, sehingga metode pengambilan sampel yang digunakan adalah teknik sensus atau sampel total. Dalam hal ini penulis berpedoman pada pendapat Burhan Bungin yang menyatakan:

Tidak semua penelitian menggunakan sampel sebagai sasaran penelitian pada penelitian tertentu dengan skala kecil, yang hanya memerlukan beberapa orang sebagai objek penelitian, ataupun beberapa

${ }^{33}$ Rahmat Syafe'i, Tinjauan Yuridis terhadap Perbankan Syariah, Artikel disampaikan dalam seminar tentang eksistensi perbankan dalam perspektif pembinaan ekonomi umat Islam di Jawa Barat, 1-3. penelitian kuantitatif yang dilakukan terhadap objek atau populasi kecil, biasanya penggunaan sampel tidak diperlukan. Hal tersebut karena keseluruhan objek dapat dijangkau oleh peneliti. Dalam istilah penelitian kuantitatif, objek penelitian yang kecil ini di sebut sebagai sample total, yaitu keseluruhan populasi merangkap sebagai sampel penelitian. ${ }^{34}$

\section{Teknik Pengumpulan Data}

Pengumpulan data dalam penelitian ini dilakukan dengan cara penelitian lapangan, yaitu terjun langsung dilokasi penelitian untuk mendapatkan data yang dibutuhkan. Penelitian lapangan dilakukan dengan cara menyebarkan instrumen penelitian berupa kuesioner kepada responden dalam bentuk pertanyaan terstruktur yaitu pertanyaan yang sudah disiapkan sebelumnya, dan responden memberikan jawaban yang telah disediakan.

Kuesioner terstruktur ini dipilih agar peneliti bisa mendapatkan data yang lebih akurat dan efektif sesuai dengan tujuan penelitian ini.

\section{Teknik Analisis Data}

Data yang diperoleh dari hasil penelitian dianalisis dengan menggunakan statistik deskriptif dan analisis statistik inferensial.

Analisis statistik deskriptif digunakan untuk mengetahui skor masing-masing variabel. Selanjutnya hasil perhitungan tersebut dideskripsikan dalam daftar frekuensi dan persentase untuk masing-masing variabel yang kemudian di distribusikan dalam bentuk kategori untuk mencapai kesimpulan.

Sedangkan analisis statistik inferensial dipergunakan untuk mengukur keeratan hubungan antar variabel dan menguji hipotesis. Teknik analisis data ini menggunakan korelasi rank spearman.
${ }^{34}$ Burhan Bungin, Metodologi Penelitian Kuantitatif, cet II (Jakarta: Kencana, 2006), 101. 
Statistik korelasi rank spearman ini ditulis dengan rumus sebagai berikut: ${ }^{35}$

$$
r_{s}=1-\frac{6 \sum d i^{2}}{n(n-1)}
$$

Keterangan:

$r_{s}=$ Rank Spearman

$d i=$ Beda (selisih) setiap pasang

$n=$ Jumlah pasangan rank

Untuk mengetahui korelasi yang terjadi, maka untuk menganalisisnya digunakan tabel panduan hasil korelasi sebagai berikut:

Tabel 1: Interval Korelasi ${ }^{36}$

\begin{tabular}{lll}
\hline No. & $\begin{array}{l}\text { Interval } \\
\text { Korelasi }\end{array}$ & Tingkat Hubungan \\
\hline 1. & $0,00-0,199$ & Sangat rendah \\
2. & $0,20-0,399$ & Rendah \\
3. & $0,40-0,599$ & Sedang \\
4. & $0,60-0,799$ & Kuat \\
5. & $0,80-1,000$ & Sangat Kuat \\
\hline
\end{tabular}

\section{HASIL PENELITIAN}

Berdasarkan data hasil penelitian mengenai status sosial ekonomi responden secara keseluruhan, penulis menjumlahkan skor yang didapat dari data penelitian tentang status sosial ekonomi. Rentang skor yang ditetapkan untuk instrumen variabel status sosial ekonomi adalah 1-74.

Berdasarkan data penelitian dapat diketahui bahwa skor terendah adalah 24 dan skor tertinggi adalah 41. Penyebaran total skor data variabel latar belakang status sosial ekonomi responden dibagi berdasarkan 3 kategori yaitu bawah, menengah dan atas. Sebagaimana yang dapat dilihat pada tabel berikut ini:

Tabel 2: Distribusi Frekuensi Variabel Status Sosial

\begin{tabular}{cccc}
\multicolumn{4}{c}{ Ekonomi } \\
\hline Interval Skor & Kategori & $\mathbf{f}$ & $\boldsymbol{\%}$ \\
\hline $0-24$ & Bawah & 1 & 4,5 \\
\hline $25-49$ & Menengah & 21 & 95,5 \\
\hline $50-74$ & Atas & 0 & 0 \\
\hline
\end{tabular}

${ }^{35}$ Ali Mauludi AC, Statistika 1: Penelitian Ekonomi Islam dan Sosial (Jakarta, PT. Prima Heza Lestari, 2006), 152-153.

${ }^{36}$ Sugiyono, Metode Penelitian Bisnis, (Jakarta: ttp., 2001), 149.
Berdasarkan analisis data yang tertera dalam tabel diatas, maka dapat dikatakan bahwa dari keseluruhan aspek yang dapat mempengaruhi status sosial ekonomi yang meliputi pendidikan, pekerjaan, kekayaan, aksesabilitas dan kedudukan, responden mayoritas masuk kategori status sosial ekonomi menengah $(95,5 \%)$, dan hanya $(4,5 \%)$ yang termasuk kategori bawah.

Adapun Selanjutnya untuk mengetahui respon kiai Babakan Ciwaringin Cirebon terhadap bank syariah secara keseluruhan, penulis menjumlahkan skor yang didapat dari variabel respon. Rentang skor yang ditetapkan untuk instrumen variabel respon terhadap bank syariah adalah 1-112. Berdasarkan data penelitian dapat diketahui bahwa skor terendah adalah 71 dan skor tertinggi adalah 94. Penyebaran total skor data variabel respon terhadap bank syariah dibagi berdasarkan kategori respon positif, netral dan respon negatif. Sebagaimana yang dapat dilihat pada tabel berikut ini:

Tabel 3: Distribusi Frekuensi Variabel Respon terhadap bank syariah

\begin{tabular}{|c|c|c|c|}
\hline $\begin{array}{c}\text { Interval } \\
\text { Skor }\end{array}$ & Kategori & $\mathbf{f}$ & $\%$ \\
\hline $0-37$ & Negatif & 0 & 0 \\
\hline $38-75$ & Netral & 8 & 36,4 \\
\hline $76-112$ & Positif & 14 & 63,6 \\
\hline
\end{tabular}

secara keseluruhan bahwa responden memiliki respon yang positif terhadap bank syariah. Hal ini dapat dilihat dari sebaran distribusi skor, dimana mayoritas masuk dalam kategori respon positif yaitu sebanyak 12 orang $(63,6 \%)$ dan kategori netral sebanyak 8 orang $(36,4 \%)$. Dan tidak ada responden yang memiliki respon negatif terhadap bank syariah.

Temuan pokok penelitian ini menunjukan bahwa mayoritas $(63,6 \%)$ Kiai Babakan Ciwaringin Cirebon memiliki respon yang positif terhadap bank syariah. Sebaliknya tidak ada yang memiliki respon negatif, namun ada $(36,4 \%)$ yang menunjukan respon yang netral. 
Dalam perspektif teori sikap, respon positif maupun netral terhadap bank syariah yang ditunjukan oleh Kiai Babakan Ciwaringin Cirebon merupakan suatu struktur dalam diri mereka yang dibentuk oleh kombinasi komponen kognitif, komponen afektif dan komponen konatif. Maksudnya, respon tersebut terbentuk karena responden punya pengetahuan, keyakinan, sikap, pandangan dan kecenderungan bertindak mengenai halikhwal bank syariah, yang diperoleh mereka melalui kerangka acuan, pengalamanpengalaman dan sosialisasi.

Berikut ini akan disajikan daftar tabel rangking Rank Spearman dari 2 variabel penelitian ini:

Tabel 4: Rangking Rank Spearman variabel status sosial ekonomi dan respon terhadap bank syariah

\begin{tabular}{ccccccc}
\hline No & $\begin{array}{c}\text { Skor } \\
\text { Status } \\
\text { Sosial } \\
\text { Ekonomi }\end{array}$ & $\begin{array}{c}\text { Skor } \\
\text { Respon }\end{array}$ & $\mathbf{R X}$ & $\mathbf{R Y}$ & $\begin{array}{c}\mathbf{R X}- \\
\mathbf{R Y} \\
(\boldsymbol{d i})\end{array}$ & $\boldsymbol{d i}^{\mathbf{2}}$ \\
\hline 1 & 34 & 88 & 17 & 14,5 & 2,5 & 6,25 \\
\hline 2 & 32 & 93 & 13 & 21 & -8 & 64 \\
\hline 3 & 27 & 74 & 6 & 4 & 2 & 4 \\
\hline 4 & 36 & 72 & 19 & 2 & 17 & 289 \\
\hline 5 & 41 & 90 & 22 & 18 & 4 & 16 \\
\hline 6 & 28 & 75 & 8 & 7 & 1 & 1 \\
\hline 7 & 24 & 94 & 1,5 & 22 & $-20,5$ & 420,25 \\
\hline 8 & 39 & 75 & 20,5 & 7 & 13,5 & 182,25 \\
\hline 9 & 31 & 71 & 10,5 & 1 & 9,5 & 90,25 \\
\hline 10 & 26 & 90 & 3,5 & 18 & $-14,5$ & 210,25 \\
\hline 11 & 34 & 90 & 17 & 18 & -1 & 1 \\
\hline 12 & 24 & 83 & 1,5 & 11 & 9,5 & 90,25 \\
\hline 13 & 32 & 89 & 13 & 16 & -3 & 9 \\
\hline 14 & 33 & 91 & 15 & 20 & -5 & 25 \\
\hline 15 & 39 & 81 & 20,5 & 9,5 & 11 & 121 \\
\hline 16 & 27 & 75 & 6 & 7 & -1 & 1 \\
\hline 17 & 32 & 88 & 13 & 14,5 & $-1,5$ & 2,25 \\
\hline 18 & 26 & 81 & 3,5 & 9,5 & 6 & 36 \\
\hline 19 & 31 & 74 & 10,5 & 4 & 6,5 & 42,25 \\
\hline 20 & 27 & 84 & 6 & 12 & -6 & 36 \\
\hline 21 & 34 & 87 & 17 & 13 & 4 & 16 \\
\hline 22 & 30 & 74 & 9 & 4 & 5 & 25 \\
\hline & & & & & & $\sum \boldsymbol{d i}^{2}=$ \\
\hline & & & & & & $\mathbf{1 6 8 8}$ \\
\hline & & & & & & \\
\hline
\end{tabular}

Untuk mengetahui apakah ada hubungan antara status sosial ekonomi kiai dengan responnya terhadap bank syariah, maka dapat dihitung dengan rumus rank spearman sebagai berikut:

$$
\begin{aligned}
& r_{s}=1-\frac{6 \sum d i^{2}}{n\left(n^{2}-1\right)} \\
& r_{s}=1-\frac{6 \times 1688}{22\left(22^{2}-\right.}=1-\frac{10128}{22(484-}=1-\frac{10128}{10626} \\
& r_{s}=1-0,953=0,047
\end{aligned}
$$

Setelah dihitung secara manual dengan alat ukur rank spearman $\left(r_{s}\right)$, ditemukan hasil sebesar $(0,047)$, karena nilai hasilnya bernilai positif (+), maka dapat disimpulkan bahwa ada hubungan positif antara status sosial ekonomi kiai dengan respon mereka terhadap bank syariah. Namun hubungan positif ini adalah hubungan positif yang sangat rendah, karena nilai hasil penghitungan $(0,047)$ berada di antara $(0,00)-(0,199)$.

Hal ini didasarkan pada tabel panduan korelasi di bawah ini:

Tabel 5: Interval Korelasi ${ }^{37}$

\begin{tabular}{ll}
\hline Interval Korelasi & Tingkat Hubungan \\
\hline $0,00-0,199$ & Sangat rendah \\
$0,20-0,399$ & Rendah \\
$0,40-0,599$ & Sedang \\
$0,60-0,799$ & Kuat \\
$0,80-1,000$ & Sangat Kuat \\
\hline
\end{tabular}

Dengan demikian hipotesa alternatif $\left(\mathrm{H}_{1}\right)$ yang menyatakan ada hubungan yang signifikan antara status sosial ekonomi dengan respon terhadap bank syariah diterima atau terbukti kebenarannya, dan sebaliknya $\left(\mathrm{H}_{0}\right)$ yang menyatakan tidak ada hubungan antara status sosial ekonomi dengan respon terhadap bank syariah ditolak. Maka dapat disimpulkan bahwa tingkat status sosial ekonomi kiai dapat mempengaruhi respon mereka terhadap bank syariah, sebagaimana yang terjadi pada kiai Babakan Ciwaringin kabupaten Cirebon.
${ }^{37}$ Sugiyono, Metode Penelitian Bisnis,149.

Al-Mustashfa, Vol. 2, No. 1, Juni 2017 
Analisis Dengan Komputerisasi (Program SPSS 12)

Hasil skor masing-masing variabel secara keseluruhan dapat dilihat pada halaman lampiran. Berikut ini akan disajikan analisis deskriptif dan korelasi rank spearman dengan menggunakan SPSS 12.

\begin{tabular}{lccccc}
\multicolumn{5}{c}{ Tabel 6: Statistik Deskriptif } \\
\hline & N & Min & Max & Mean & $\begin{array}{c}\text { Std. } \\
\text { Deviation }\end{array}$ \\
\hline $\begin{array}{l}\text { Status Sosial } \\
\text { Ekonomi } \\
\text { (X) }\end{array}$ & 22 & 24 & 41 & 31.23 & 4.840 \\
\hline $\begin{array}{l}\text { Respon } \\
\text { terhadap }\end{array}$ & 22 & 71 & 94 & 82.68 & 7.687 \\
$\begin{array}{l}\text { Bank Syariah } \\
\text { (Y) }\end{array}$ & & & & & \\
\hline $\begin{array}{l}\text { Valid N } \\
\text { (listwise) }\end{array}$ & 22 & & & & \\
\hline
\end{tabular}

Berdasarkan tabel diatas dapat dilihat bahwa variable $X$ memiliki nilai rata-rata 31.23, dengan nilai rata-rata 31.23 maka dapat dikatakan bahwa mayoritas status sosial ekonomi responden termasuk kategori menengah. Nilai minimum 24, nilai maximum 41, dengan standar deviasi 4.840. Sedangkan variable $\mathrm{Y}$ memiliki nilai ratarata 82.68, dengan nilai rata-rata 82.68 ini, maka dapat di katakan bahwa responden memiliki respon yang positif. Nilai minimum 71, nilai maximum 94 dengan standar deviasi 7.687.

Tabel 7: Korelasi Non Parametrik

\begin{tabular}{|c|c|c|c|c|}
\hline & & & $\begin{array}{c}\text { Status } \\
\text { Sosial } \\
\text { Ekonom } \\
\text { i } \\
\text { (X) }\end{array}$ & $\begin{array}{c}\text { Respon } \\
\text { terhada } \\
\text { p Bank } \\
\text { Syariah } \\
\text { (Y) }\end{array}$ \\
\hline \multirow[t]{6}{*}{$\begin{array}{l}\text { Spearman' } \\
\text { s rho }\end{array}$} & $\begin{array}{l}\text { Status } \\
\text { Sosial } \\
\text { Ekonom } \\
\text { i }\end{array}$ & $\begin{array}{l}\text { Correlatio } \\
n \\
\text { Coefficien } \\
t\end{array}$ & 1.000 & 0.039 \\
\hline & & $\begin{array}{l}\text { Sig. }(2- \\
\text { tailed) }\end{array}$ & . & 0.864 \\
\hline & & $\mathrm{N}$ & 22 & 22 \\
\hline & $\begin{array}{l}\text { Respon } \\
\text { terhada } \\
\mathrm{p} \\
\text { Bank } \\
\text { Syariah }\end{array}$ & $\begin{array}{l}\text { Correlatio } \\
n \\
\text { Coefficien } \\
t\end{array}$ & 0.039 & 1.000 \\
\hline & & $\begin{array}{l}\text { Sig. (2- } \\
\text { tailed) }\end{array}$ & 0.864 & \\
\hline & & $\mathrm{N}$ & 22 & 22 \\
\hline
\end{tabular}

Berdasarkan data yang dihitung dengan SPSS 12 seperti terlihat dalam tabel 7 diatas ditemukan hasil korelasi sebesar
(0.039), karena nilai hasilnya bernilai positif (+), maka dapat disimpulkan bahwa ada hubungan positif antara status sosial ekonomi kiai dengan respon mereka terhadap bank syariah. Namun berdasarkan tabel interval korelasi sebagaimana terlihat dalam tabel 4.19 diatas, hubungan positif ini adalah hubungan positif yang sangat rendah, karena nilai hasil penghitungan $(0,039)$ berada di antara $(0,00)-(0,199)$.

Dengan demikian berdasarkan perhitungan SPSS 12 diatas menunjukan kesimpulan yang sama dengan perhitungan secara manual, yaitu hipotesa alternatif $\left(\mathrm{H}_{1}\right)$ yang menyatakan ada hubungan yang signifikan antara status sosial ekonomi dengan respon terhadap bank syariah diterima atau terbukti kebenarannya, dan sebaliknya $\left(\mathrm{H}_{0}\right)$ yang menyatakan tidak ada hubungan antara status sosial ekonomi dengan respon terhadap bank syariah ditolak. Maka dapat disimpulkan bahwa tingkat status sosial ekonomi kiai dapat mempengaruhi respon mereka terhadap bank syariah, sebagaimana yang terjadi pada kiai Babakan Ciwaringin kabupaten Cirebon.

\section{KESIMPULAN}

Berdasarkan hasil analisis data dan pembahasan yang telah disajikan pada bab sebelumnya, maka dapat di kemukakan 3 (tiga) kesimpulan, yaitu pertama, secara keseluruhan status sosial ekonomi Kyai Babakan Ciwaringin Cirebon ditinjau dari dimensi pendidikan, pekerjaan, kekayaan, aksesabilitas dan kedudukan di dalam masyarakat termasuk dalam kategori menengah. Hal ini ditunjukkan pada tabel 2 yang berisi sebaran total skor dari variabel status sosial ekonomi responden. Semua responden termasuk kategori menengah yaitu sebanyak 22 orang (100\%).

Kedua, secara keseluruhuan respon Kyai Babakan Ciwaringin Cirebon terhadap bank syariah adalah sangat positif. Hal ini ditunjukkan pada tabel 3 yang berisi sebaran total skor dari variabel respon terhadap bank syariah, mayoritas masuk kategori baik, yaitu sebanyak 20 orang $(91 \%)$ dan sangat baik sebanyak 2 orang (9\%). 
Dan ketiga, antara status sosial ekonomi kyai Babakan Ciwaringin Cirebon dengan responnya terhadap bank syariah terdapat korelasi signifikan. Angka 0,184 dari hasil perhitungan rank spearmen menunjukan bahwa keduanya terdapat korelasi positif signifikan yang saling mempengaruhi satu sama lain. Sehingga dalam kesimpulan akhir penulis menyebutkan bahwa jika status sosial ekonomi kyai Babakan Ciwaringin Cirebon tinggi, maka responnya terhadap bank syariah akan naik dan sebaliknya. Akan tetapi kenaikannya tidak signifikan karena hubungannya sangat rendah.

\section{Buku-buku}

\section{DAFTAR PUSTAKA}

Abdur Rahman, Tindak Pidana Dalam Syari'at Islam, Jakarta: Rineka Cipta, 1992.

Abidin, Zainal, Pemidanaan, Pidana dan Tindakan dalam Rancangan KUHP. Jakarta: Elsam, 2005.

Anckar, Carsten, Determinant of the Death Penalty. London and New York: Rooutledge, 2004.

Asmarawati, Tina, Hukuman Mati dan Penerapannya di Indonesia. Yogyakarta: Deepublish Publisher, 2013.

Audah, Abdul Qadir, Al-Tasyri' al-Jina'i alIslami: Muqaranan bi al-Qanun alWadh'i, juz I/ Beirut: Dar al-Katib al-'Azali, tth.

Bahiej, Ahmad, "Sejarah dan Problematika Hukum Pidana Materiel di Indonesia", dalam Sosio-Religia, Vol. 4, Agustus 2005.

Djazuli, A., Fiqh Jinayah: upaya menanggulangi kejahatan dalam Islam. Jakarta: PT. Raja Grafindo Persada, 2000.

Hamzah, Andi, Hukum Acara Pidana Indonesia, cet. I. Jakarta: Sinar Grafika, 2009.

ICDP, How States Abolish the Death Penalty. Geneva: ICDP, 2014.
Kasim, Ifdhal, "Ke Arah Mana Pembaruan KUHP? Tinjauan Kritis atas RUU KUHP". Jakarta: ELSAM, 2005.

Lippman, Matthew, "Islamic Criminal Law and Procedure: Religious Fundamentalism vs. Modern Law", dalam Boston College International and Comparative Law, Vol. 12, Issue I (Juni, 1989).

Makdisi, George A. Cita Humanisme Islam: Panorama Kebangkitan Intelektual dan Budaya Islam dan Pengaruhnya terhadap Renaisans Barat. Jakarta: Serambi, 2005.

Munajat, Makhrus, Dekonstruksi Hukum Pidana Islam. Jogjakarta: Logung Pustaka, 2004.

Walker, Ida, The Death Penalty. Minnesota: ABDO Publishing Company, 2008.

Widodo, Supriyadi, dkk., Hukuman Mati dalam $R$ KUHO: Jalan Tengah yang Meragukan. Jakarta: ICJR dan Aliansi Nasional Reformasi KUHP, 2015.

Zulfa, Eva Achjani, "Menakar Kembali Keberadaan Pidana Mati (Suatu Pergeseran Paradigma Pemidanaan di Indonesia", dalam Lex Jurnalica, Vol. 2, No. 2 (April, 2007).

\section{Artikel Jurnal atau Lainnya}

"Mengapa Hukuman Mati Tak Relevan Lagi?: Laporan Utama", dalam Buletin Asasi, edisi November Desember 2014.

Appadorai A. "The Doctrine of Humanism", dalam India International Centre Quarterly, Vol. 15, No. 2 (Summer, 1988).

Christianto, Hwian, "Penafsiran Hukum Progresif dalam Perkara Pidana", dalam Mimbar Hukum, Vol. 23, No. 3 (Oktober, 2011.

Lynch, Colman, “Indonesia's Use of Capital Punishment for Drugs-Trafficking Crime: Legal Obligation, Extralegal Factors, and the Bali Nine Case", dalam Columbian Human Rights Law Review, edisi 3 (Mei, 2009). 
Rahardjo, Satjipto, "Menjalankan Hukum dengan Kecerdasan Spiritual", Kompas, 30 Desember 2002.

Rahardjo, Satjipto, "Sesuai Prosedur itu Tidak Cukup", Kompas, 07 Oktober 2004.

Yanto Supriyadi, "Penerapan Hukum Progresif dalam Penegakan Hukum di tengah Krisis Demokrasi", dalam Jurnal Hukum, No. 2, Vol. 17, (April, 2010).

Yunshi, Lin, "Closer Look: Putting China on the Path to Ending Capital Punishment", Caixin Online, 4 Maret 2013, diakses dari http://english.caixin.com/2013-0403/100509655.html

\section{Media Massa}

"China court gives out new death penalty years after executing wrong man for rape-murder", The Strairs Time, 9 Februari 2015, diakses dari http://www.straitstimes.com/asia/ea st-asia/china-court-gives-out-newdeath-penalty-years-afterexecuting-wrong-man-for-rape;

"Eksekusi Pidana Mati Tidak Melanggar HAM", dalam Detik.com, Senin, 17 Februari 2003, diakses dari http://www.hukumonline.com/berit a/baca/hol7460/eksekusi-pidanamati-tidak-melanggar-konstitusi

\section{Peraturan dan Instrumen Hukum} Internasional

Deklarasi Universal Hak Asasi Manusia tahun 1948 dan Kovenan Internasional Hak Sipil dan Politik tahun 1966.

Putusan PUU/V/2007 tentang Hukuman Mati

Undang-undang Dasar (UUD) 1945

UU No. 12 Tahun 2005 Tentang Ratifikasi Kovenan Internasional Hak Sipil dan Politik. 